\title{
Epidemiology of Saint Louis encephalitis virus in the Brazilian Amazon region and in the State of Mato Grosso do Sul, Brazil: elevated prevalence of antibodies in horses
}

Epidemiologia do vírus da encefalite Saint Lovis na Amazônia brasileira e no Estado do Mato Grosso do Sul, Brasil: elevada prevalência de anticorpos em equinos

Epidemiología del virus de la encefalitis de San Luis en la Amazonia brasileña y en el Estado de Mato Grosso do Sul (Brasil): alta prevalencia de anticuerpos en equinos

Sueli Guerreiro Rodrigues

Seção de Arbovirologia e Febres Hemorrágicas, Instituto Evandro

Chagas/SVS/MS, Ananindeua, Pará, Brasil

Otávio Pinheiro Oliva

Pan American Health Organization, Washington, DC, EUA

Francisco Anilton Alves Araujo

COVEV/CGDT/DEVEP, Secretaria de Vigilância em Saúde, Ministério

da Saúde, Brasília, Distrito Federal, Brasil

Lívia Carício Martins

Seção de Arbovirologia e Febres Hemorrágicas, Instituto Evandro

Chagas/SVS/MS, Ananindeua, Pará, Brasil

Jannifer Oliveira Chiang

Seção de Arbovirologia e Febres Hemorrágicas, Instituto Evandro

Chagas/SVS/MS, Ananindeua, Pará, Brasil

Daniele Freitas Henriques

Seção de Arbovirologia e Febres Hemorrágicas, Instituto Evandro

Chagas/SVS/MS, Ananindeua, Pará, Brasil
Eliana Vieira Pinto da Silva

Seção de Arbovirologia e Febres Hemorrágicas, Instituto Evandro

Chagas/SVS/MS, Ananindeua, Pará, Brasil

Daniela Sueli Guerreiro Rodrigues

Seção de Arbovirologia e Febres Hemorrágicas, Instituto Evandro Chagas/SVS/MS, Ananindeua, Pará, Brasil

Assis do Socorro Correa dos Prazeres

Seção de Arbovirologia e Febres Hemorrágicas, Instituto Evandro Chagas/SVS/MS, Ananindeua, Pará, Brasil

José Tavares-Neto

Departamento de Medicina, Faculdade de Medicina da Bahia, Universidade Federal da Bahia, Salvador, Bahia, Brasil

Pedro Fernando da Costa Vasconcelos

Seção de Arbovirologia e Febres Hemorrágicas, Instituto Evandro Chagas/SVS/MS, Ananindeua, Pará, Brasil

\begin{abstract}
The immunity of horses $(n=1401)$ against Saint Louis encephalitis virus (SLEV) was investigated in the Brazilian Amazon region (Bragança/Pará, Salvaterra/Pará, Macapá/Amapá and Rio Branco/Acre) and Maracaju, State of Mato Grosso do Sul, by the hemagglutination inhibition (HI) and plaque reduction neutralization (PRNT) tests. HI and neutralizing antibodies specific (monotypic reactivity, MR) for SLEV and other flaviviruses included in the tests were detected, as was cross-reactivity (CR) against flaviviruses. In the HI test, MR was observed in 248 (17.7\%) serum samples, 137 of which were (55.2\%) against SLEV; CR was detected in 380 (27.1\%). The frequency of MR against SLEV was significantly higher in Macapá and CR was significantly higher in Salvaterra. In the PRNT, neutralization of SLEV was observed in 713 (50.9\%) samples, and the prevalence of neutralizing antibodies was significantly higher in Macapá than in Salvaterra $(p=0.0083)$. This study adds new data regarding the immunity of horses against SLEV in Brazil, and it confirms the wide distribution of SLEV and the diversity of flaviviruses in the country, as well as the apparent absence of disease in SLEV-infected horses.
\end{abstract}

Keywords: Encephalitis, St. Louis; Horses; Serologic Tests; Encephalitis, Arbovirus.

\footnotetext{
Sueli Guerreiro Rodrigues

Instituto Evandro Chagas

Seção de Arbovirologia e Febres Hemorrágicas

Rodovia BR316, km 7, s/nº, Levilândia

CEP: 67030-000 Ananindeva-Pará-Brasil

E-mail:suelirodrigues@iec.pa.gov.br
}

Correspondência / Correspondence / Correspondencia: 


\section{INTRODUCTION}

Saint Louis encephalitis virus (SLEV) is an encephalitogenic arbovirus that taxonomically belongs to the Japanese encephalitis virus complex within the genus Flavivirus, family Flaviviridae ${ }^{2}$. SLEV is widely distributed throughout the western hemisphere; however, strains isolated in the United States and Canada are apparently more virulent than those isolated in the Caribbean and Central and South America ${ }^{4}$. Mosquitoes of the genus Culex and wild birds serve as the primary amplification host for SLEV ${ }^{21,24,16}$. Horses, which are typically dead-end hosts of other encephalitogenic arboviruses, do not show elevated viremia or clinical disease when infected with SLEV through the bite of a mosquito or subcutaneous inoculation ${ }^{16,24}$. Although antibodies against SLEV are detected in naturally infected horses ${ }^{10,9}$, there is a lack of data regarding the true role of these animals in the transmission of SLEV in nature.

Encephalitis is one of the most severe clinical manifestations of arbovirus infection, and it may result in death or leave severe sequelae characterized by residual motor and/or psychological dysfunction in survivors. Arbovirus infection thus represents an important public and veterinary health problem ${ }^{21,24}$. Infection of humans with SLEV does not always result in the clinical manifestations of encephalitis and often passes unnoticed, except during epidemics $^{16}$. The apparent to inapparent infection ratio estimated from epidemics ranges from 1:16 to $1: 425$ depending on the virulence of the SLEV strain and the history of infection of the population ${ }^{11,16}$. Lethality rates usually reach $5-20 \%{ }^{22}$ and are always higher among elderly patients $(>75 \text { years) })^{16}$.

In Brazil, SLEV has been isolated frequently from hematophagous arthropods and birds, especially in the Brazilian Amazon region, but only rarely from humans despite a prevalence of hemagglutination-inhibiting antibodies ranging from $1 \%$ to $5 \%$ in serological studies $^{21,23,24}$. In the 1980s, four small SLEV epizootics involving wild birds and sentinel animals were reported in the State of Pará in forests adjacent to Belém ${ }^{23}$. However, no information exists regarding the rates of immunity of horses against SLEV in Brazil.

In Brazil, three SLEV strains were isolated from the blood of patients without neurological symptoms, two from Pará with fever and jaundice ${ }^{14,24}$ and one from São Paulo with a clinical suspicion of dengue ${ }^{17}$. Recently, SLEV was detected by molecular techniques in four patients with dengue-like clinical symptoms and two with a suspicion of viral meningoencephalitis from the Municipality of São José do Rio Preto, São Paulo ${ }^{12,13}$.

It should be emphasized that the interpretation of flavivirus serological results requires caution because of the complex combination of cross-reactivity (CR) between antibodies and sequential (secondary) infections with different flaviviruses ${ }^{8}$. Antibodies produced during an infection normally react against antigens of various flaviviruses in serological tests. This CR is even stronger during secondary infections. The monotypic specificity (monotypic reactivity - MR) of lgG in primary infections, i.e., the production of antibodies against antigens from only one flavivirus, was recognized early. Serological tests for the detection of flaviviruses applied to Brazilian populations tend to show high rates of $C R$, since 11 different flaviviruses have already been isolated in $\mathrm{Brazi}^{3,2,25}$.

CR between flaviviruses can be clearly demonstrated in the hemagglutination inhibition (HI) test, a method that permits the simultaneous testing of a large number of samples against different arboviruses. Thus, this test provides knowledge about the immune response of a certain population to arboviruses.

The known specificity of neutralization tests generally permits the identification of a viral agent responsible for manifestations during primary infection, but this fact does not apply to secondary infections when the test is used for serodiagnosis in vitro. The plaque reduction neutralization test (PRNT) is currently the most widely used in vitro test. However, despite the importance of the PRNT for evaluating the efficacy of vaccines and for confirming serodiagnoses due to its high specificity and sensitivity, the lack of a standard procedure and of diagnostic criteria results in wide variations between laboratories ${ }^{8,18}$.

This study investigated the immunity of horses against SLEV in four municipalities of the Brazilian Amazon region and in the State of Mato Grosso do Sul in order to contribute to a better understanding of the epidemiology of this virus.

\section{MATERIALS AND METHODS}

\section{STUDY DESIGN}

A descriptive cross-sectional observational study.

\section{HORSE SERA}

Serum samples were collected from 1401 horses selected by convenience sampling between March and September 2005. The serological surveys were conducted on farms in the Municipalities of Bragança $(n=244)$ and Salvaterra ( $n=272)$, State of Pará, and Macapá $(n=179)$, State of Amapá, and at state farm shows in Rio Branco ( $n=$ 333), State of Acre, and Maracaju ( $n=373)$, State of Mato Grosso do Sul (Figure 1). The horses were healthy at the time of blood collection and had no history of vaccination against flaviviruses.

This study is part of a larger investigation on equine encephalitis viruses and WestNile virus (WNV) conducted by the Pan American Health Organization (PAHO) /Centers for Disease Control and Prevention (CDC) in various Latin American countries. 


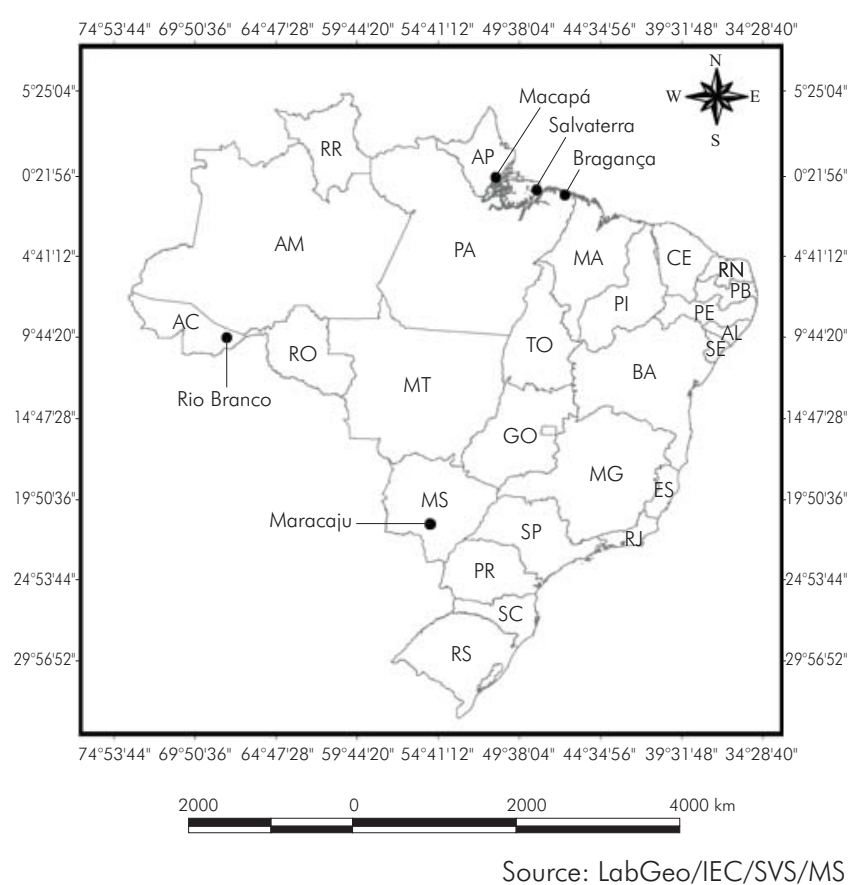

Brazilian Amazon region: AC - Acre, AM - Amazonas, AP - Amapá, AL Alagoas, PA - Pará, RO - Rondônia, RR - Roraima, TO - Tocantins, MA Maranhão (partially), and MT - Mato Grosso (partially);

MS: Mato Grosso do Sul.

Figure 1 - Locations of the municipalities in the Brazilian Amazon region and State of Mato Grosso do Sul where the serological surveys of horses were conducted: Bragança $(n=244)$, Salvaterra $(n=$ 272), Macapá ( $n=179)$, Rio Branco ( $n=333)$, and Maracaju $(\mathrm{n}=373)$

\section{HEMAGGLUTINATION INHIBITION TEST}

For the $\mathrm{HI}$ test adapted to microplates ${ }^{19}$, serum samples were tested against antigens from the SLEV, Rocio (ROCV), Ihéus (ILHV), Cacipacoré (CPCV) and Bussuquara (BSQV) flaviviruses. First, the samples were screened at a dilution of $1: 20$ against antigens containing four hemagglutination units, and positive sera were titrated up to a dilution (by factors of 2) of $1: 1280$.

\section{PLAQUE REDUCTION NEUTRALIZATION TEST}

The PRNT was carried out simultaneously for SLEV and another genetically closely related flavivirus (WNV) according to the protocol for the detection of antibodies against flaviviruses (yellow fever virus) ${ }^{20}$. Microtiter plates and Vero cells at a concentration of $1.6 \times 10^{5}$ were used. The samples were tested at two-fold serial dilutions ( $1: 10$ to $1: 640$ ) against a mean of 20 plaque forming units (PFU) of SLEV (ChimeriVax-SLEV) and 16 PFU of WNV (ChimeriVaxWNV). The plates were incubated for seven and six days, respectively. The titer of the neutralizing antibodies was defined as the reciprocal of the serum dilution that reduced the number of plaques by $50 \%$. Samples containing neutralizing antibodies against both viruses were considered to be positive for one of them when the antibody titer was four times higher than that obtained for the other virus; otherwise, the sample was said to present CR against the virus in question ${ }^{6}$.
Since the PRNT for SLEV and WNV requires a biosafety level 3 laboratory (NB-3), highly attenuated chimerae of these viruses with vaccine strain 17D of yellow fever virus developed for diagnostic and surveillance purposes ${ }^{15,7}$ were kindly donated by the CDC to the Evandro Chagas Institute.

In this study, MR refers to the presence of antibodies to a single flavivirus; CR refers to the presence of antibodies to two or more flaviviruses ${ }^{6,8,19}$ (Table 1).

Table 1 - Definitions of monotypic and cross-reactive responses to flaviviruses using the $\mathrm{IH}$ and PRNT tests

\begin{tabular}{|c|c|c|c|}
\hline & Cut-off & Monotypic reactivity & Cross-reactivity \\
\hline $\mathrm{IH}$ & $1: 20$ & $\begin{array}{l}\text { Presence of antibodies } \\
\text { with titers } \geq 1: 20 \text { for a } \\
\text { single flavivirus }\end{array}$ & $\begin{array}{l}\text { Presence of antibodies } \\
\text { with titers } \geq 1: 20 \text { for two } \\
\text { or more flaviviruses }\end{array}$ \\
\hline $\mathrm{PRNT}_{50}{ }^{*}$ & $1: 10$ & $\begin{array}{l}\text { Presence of antibodies } \\
\text { with titers } \geq 1: 10 \text { for } \\
\text { SLEV orWNV }\end{array}$ & $\begin{array}{l}\text { Presence of antibodies } \\
\text { for SLEV and WNV in } \\
\text { titers } \geq 1: 10^{\dagger}\end{array}$ \\
\hline
\end{tabular}

\footnotetext{
*50 percent plaque reduction neutralizing antibody.

${ }^{\dagger}$ The samples with CR were considered positive for SLEV when the antibody titer was four times higher than that obtained for WNV.
}

\section{STATISTICALANALYSIS}

The prevalences of $\mathrm{HI}$ and neutralizing antibodies were compared by a binomial test of proportions for independent samples with the level of significance set at $5 \%$ (0.05). Statistical analysis was performed using the BioEstat program version $5.0^{\prime}$.

\section{RESULTS}

$\mathrm{HI}$ antibodies against the tested flaviviruses were detected in 628 (44.8\%) of the 1401 equine serum samples, with $380(27.1 \%)$ presenting CR between flaviviruses and 248 (17.7\%) presenting MR against the following viruses: $\operatorname{SLEV}(\mathrm{n}=137,9.8 \%), \operatorname{ILHV}(\mathrm{n}=64$, $4.6 \%), \operatorname{ROCV}(n=30,2.1 \%), \operatorname{CPCV}(n=16,1.1 \%)$, and $\operatorname{BSQV}(\mathrm{n}=1,0.1 \%)$. Of the 248 samples presenting $M R$, 137 (55.2\%) were reactive against SLEV.

Analysis of the distribution of $\mathrm{Hl}$ antibodies according to municipality (Figure 2) showed a higher prevalence among horses from the Municipalities of Macapá/Amapá (67\%) and Salvaterra/Pará (62.9\%). The number of samples presenting MR against SLEV was significantly higher in Macapá than in Bragança ( $p=0.0022)$, Salvaterra $(p=$ $0.0031)$, Rio Branco $(p=0.0043)$, or Maracaju ( $p=$ 0.0063).

Samples from Salvaterra presented MR against antigens from all flaviviruses included in the test, and the highest frequency of MR was observed for ILHV ( $n=41,15.5 \%)$ (Figure 2). In addition, the frequency of CR between flaviviruses was significantly higher among samples from Salvaterra ( $p=0.037)$ than among samples from Macapá or the other municipalities. 


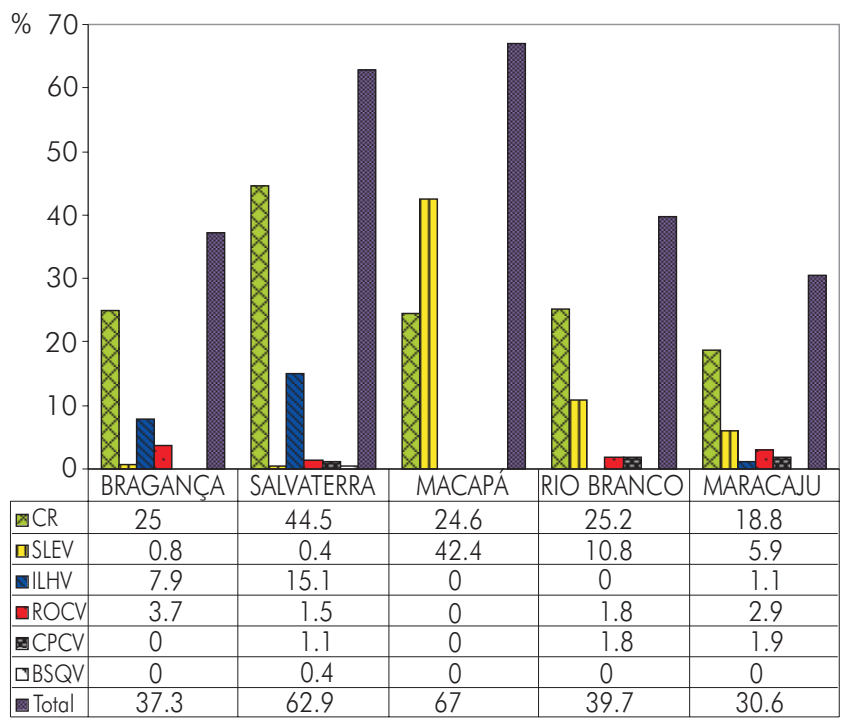

CR - cross-reactivity; SLEV - Saint Louis encephalitis virus; ILHV - Ilhéus virus; ROCV - Rocio virus; CPCV - Cacipacoré virus; BSQV - Bussuquara virus.

Figure 2 - Percentage of equine serum samples presenting hemagglutination-inhibiting antibodies against SLEV, ILHV, ROCV, CPCV and BSQV and crossreactivity to flaviviruses according to municipality

Using the PRNT, neutralizing antibodies against SLEV were detected in 713 (50.9\%) samples, with their frequency ranging from $34.6 \%(n=94)$ in Salvaterra to $60.9 \%(n=$ 109) in Macapá (Figure 3).

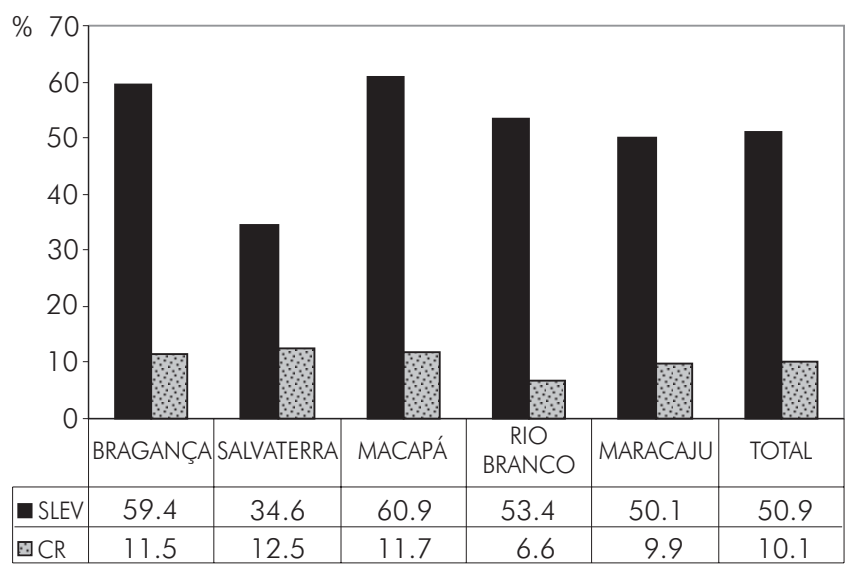

CR - cross-reactivity; SLEV - Saint Louis encephalitis virus.

Figure 3 - Percentage of equine serum samples presenting neutralizing antibodies (PRNT) against SLEV and cross-reactivity according to municipality

The prevalence of neutralizing antibodies was significantly higher in samples from Macapá when compared to Salvaterra $(p=0.0083)$ and Maracaju $(p=$ 0.0176 ), but no significant difference was observed compared to samples from Bragança $(p=0.7608)$ or Rio Branco $(p=0.1058)$.

CR was detected by the PRNT in 142 (10.1\%) serum samples from all five municipalities, with the frequency ranging from $6.6 \%$ in Rio Branco/Acre to $12.5 \%$ in Salvaterra. In addition, 123 (19.5\%) of the HI-positive samples tested negative for SLEV and WNV in the PRNT.

\section{DISCUSSION}

This study, the first of this type conducted in Brazil, detected $\mathrm{HI}$ and neutralizing antibodies against SLEV in naturally infected horses in five geographically distant municipalities (Figures 1, 2 and 3). Our results demonstrate the widespread distribution of this virus, and they agree with previous studies conducted on humans and wild vertebrates in Brazil (especially in the Brazilian Amazon region) reporting a prevalence of $\mathrm{Hl}$ antibodies ranging from 0.1 to $5.0 \%^{21,24}$.

It should be mentioned that the horses from Rio Branco/Acre and Maracaju/Mato Grosso do Sul were from various regions of the state, whereas the animals from Macapá/Amapá, Salvaterra/Pará and Bragança/Pará belonged to a selected area within each municipality and had no history of transfer or vaccination, indicating that the infections in these latter areas were autochthonous.

The results of the $\mathrm{HI}$ test suggest a notable occurrence of SLEV infection in the Municipality of Macapá (Amapá), where the high frequency of antibodies was due to MR against SLEV. Furthermore, a predominance of MR against ILHV was observed in Bragança and Salvaterra, Pará State. This virus is widely distributed in Central and South America and the prevalence of neutralizing antibodies against ILHV in the Amazon Region ranges from 3 to $36 \% \%^{21,25}$. MR against ILHV was also detected in horses that participated in the state farm show of Maracaju, Mato Grosso do Sul, in agreement with the previous observation of antibodies against ILHV in horses from the Brazilian Pantanal area ${ }^{5}$.

The $\mathrm{HI}$ test also showed that the horse populations studied possessed an immune response pattern consistent with that of a population exposed to infection with different flaviviruses, in agreement with the previously demonstrated diversity of flaviviruses in $\mathrm{Brazi}^{21,3,2,25}$. In addition, the variety of MR against other flaviviruses suggests the possible cocirculation of SLEV with these viruses. This fact was well documented in the municipality of Salvaterra, where samples presented the highest frequency of CR and MR against antigens from all flaviviruses included in the study. In this respect, the PRNT results also suggest the occurrence of infection with other flaviviruses in the horse populations studied, with $10.1 \%$ of the samples being characterized as cross-reactive and $19.5 \%$ of the $\mathrm{HI}$-positive samples being negative for SLEV and WNV.

The serological evidence presented here, together with the lack of reports of epizootics in horses, suggests the occurrence of inapparent, subclinical or oligosymptomatic infections. This agrees with previous studies suggesting that SLEV normally does not cause apparent clinical disease in horses ${ }^{24,16}$.

In conclusion, the SLEV activity in horses and possible co-circulation of other flaviviruses observed in the present study agree with studies investigating human cases of SLEV infection diagnosed in São Paulo with dengue as the main clinical suspicion ${ }^{17,12,13}$. The small number of human cases of SLEV infection is probably due to the occurrence of inapparent infection, but it may also be the result of subdetection of clinical cases due to the difficulty of making a differential diagnosis. 


\section{ACKNOWLEDGEMENTS}

We thank Basílio Silva Buna, Luiz Roberto Oliveira da Costa, and Geraldo Mendes da Silva for help with the field work and laboratory activities. We are also indebted to $\mathrm{dr}$. Barbara Johnson (CDC) for kindly providing the chimera
(ChimeriVax-SLE and ChimeriVax-WN). This work has received financial support from Instituto Evandro Chagas/SVS/MS, PAHO (grant 109/2005) and National Counsel of Technological and Scientific Development (Conselho Nacional de Desenvolvimento Científico e Tecnológico - CNPq) (grant 300460/2005-8).

\section{Epidemiologia do vírus da encefalite Saint Louis na Amazônia brasileira e no Estado do Mato Grosso do Sul, Brasil: elevada prevalência de anticorpos em equinos \\ RESUMO}

A imunidade de equinos $(n=1401)$ contra o vírus da encefalite Saint Louis (SLEV) foi investigada na Amazônia brasileira (Bragança/PA, Salvaterra/PA, Macapá/AP e Rio Branco/AC) e Maracaju, no Estado do Mato Grosso do Sul, por meio de testes de inibição da hemaglutinação $(\mathrm{IH})$ e neutralização por redução de placas (PRNT). Foram detectados anticorpos $\mathrm{IHe}$ neutralizantes específicos (reações monotípicas - RM) para SLEV e outros flavivírus incluídos nos testes, assim como reações cruzadas para flavivírus. Pelo teste de $\mathrm{IH}$, RM foram observadas em $248(17,7 \%)$ amostras de soro, 137 (55,2\%) para SLEV, e RC para flavivírus foram detectadas em 380 (27,1\%). A frequência de RM para SLEV e de RC foi significativamente maior em Macapá e Salvaterra, respectivamente. Pelo PRNT, foi observada a neutralização do SLEV em 713 (50,9\%) amostras, e a prevalência de anticorpos neutralizantes foi significativamente maior em Macapá, em comparação com Salvaterra $(p=0,0083)$. Este estudo traz novos dados a respeito da imunidade de equinos contra SLEV no Brasil, e confirma a ampla distribuição de SLEV e a diversidade de flavivírus no País, bem como a aparente ausência de doenças em equinos infectados por SLEV.

Palavras-chave: Vírus da Encefalite St. Louis; Cavalos; Testes Sorológicos; Encefalite por Arbovirus.

\section{Epidemiología del virus de la encefalitis de San Luis en la Amazonia brasileña y en el Estado de Mato Grosso do Sul (Brasil): alta prevalencia de anticuerpos en equinos \\ RESUMEN}

La inmunidad de los equinos ( $n=1401$ ) contra el virus de la encefalitis de San Luis (VESL) fue investigado en la Amazonia brasileña (Bragança/Pará, Salvaterra/Pará, Macapá/Amapá y Rio Branco/Acre) y Maracaju en el Estado de Mato Grosso do Sul, a través de pruebas de inhibición de la hemaglutinación $(\mathrm{IH})$ y la neutralización por reducción de placas (PNRP). Se detectaron anticuerpos $\mathrm{IH}$ y neutralizantes específicos (reacciones monotípicas, RM) para VESL y otros flavivirus incluidos en las pruebas, así como reacciones cruzadas (RC) para flavivirus. En la prueba de IH se observaron RM en $248(17,7 \%)$ muestras de suero, 137 (55,2\%) para VESL, y las RC fueron detectadas en 380 (27,1\%). La frecuencia de RM del VESL y la R fue significativamente mayor en Macapá y Salvaterra, respectivamente. Por el PNRP, se observó la neutralización del VESL en $713(50,9 \%)$ muestras, y la prevalencia de anticuerpos neutralizantes fue significativamente mayor en Macapá, si se compara con Salvaterra $(p=0,0083)$. Este estudio proporciona nuevos datos sobre la inmunidad de los equinos frente al VESL en Brasil, y confirma la amplia distribución del VESL y la diversidad de flavivirus en este país, así como la aparente ausencia de enfermedad en los equinos infectados por el VESL.

Palabras clave: Encefalitis de San Luis; Caballos; Pruebas Serológicas; Encefalitis por Arbovirus.

\section{REFERENCES}

1 Ayres M, Ayres Júnior M, Ayres DL, Santos AS. Bioestat 5.0: aplicações estatísticas nas áreas das ciências biológicas e médicas. Belém: Sociedade Civil Mamirauá; 2007.

2 Calisher $\mathrm{CH}$, Gould EA. Taxonomy of the virus family Flaviviridae. In: Maramorosch K, Murphy FA, Shatkin AJ, editors. Advances in virus research. San Diego: Academic Press; 2003. Vol. 59, p. 1-19.

3 Figueiredo LT. The Brazilian flaviviruses. Microbes Infect. 2000 Nov;2(13): 1643-9.

4 Gubler DJ, Kuno G, Markoff L. Flaviviruses. In: Knipe DM, Howley PM, editors. Fields virology. 5th ed. Philadelphia: Lippincott Williams \& Wilkins; 2007. p. $1153-252$.
5 Iversson LB, Silva RA, Travassos da Rosa AP, Barros VL. Circulation of eastern equine encephalitis, western equine encephalitis, Ilhéus, Maguari and Tacaiuma viruses in equines of the Brazilian Pantanal, South America. Rev Inst Med Trop Sao Paulo. 1993 JulAug;35(4):355-9.

6 Johnson BW, Kosoy O, Martin DA, Noga AJ, Russell BJ, Johnson $A A$, et al. West Nile virus infection and serologic response among persons previously vaccinated against yellow fever and Japanese encephalitis viruses. Vector Borne Zoonotic Dis. $2005 ; 5(2): 137-45$.

7 Komar N, Langevin S, Monath TP. Use of a surrogate chimeric virus to detect West Nile virus-neutralizing antibodies in avian and equine sera. Clin Vaccine Immunol. 2009 Jan;6(1):134-5. 
8 Kuno G. Serodiagnosis of flaviviral infections and vaccinations in humans. In: Maramorosch K, Murphy FA, Shatkin AJ, editors. Advances in virus research. San Diego: Academic Press; 2003. Vol. 61, p. 3-65.

9 Marlenee NL, Loroño-Pino MA, Beaty BJ, Blitvich BJ, Fernández Salas I, Contreras Cordero JF, et al. Detection of antibodies to West Nile and Saint Louis encephalitis viruses in horses. Salud Publica Mex. 2004 Sep-Oct;46(5):373-5.

10 Mettler NE, Fernández AS, Di Santo MI, Pardo DA. Flavivirus: serological survey in horses from the Tandil area. Rev Argent Microbiol. 1985;17(1):47-9.

11 Monath TP, editor. St. Louis encephalitis. Washington: American Public Health Association; 1980. Epidemiology. p. 239-312.

12 Mondini A, Bronzoni R, Cardeal I, Santos T, Lázaro E, Nunes $S$, et al. Simultaneous infection by DENV-3 and SLEV in Brazil. J Clin Virol. 2007 Sep;40(1):84-6.

13 Mondini A, Cardeal ILS, Lázaro E, Nunes SH, Moreira CC, Rahal P, et al. Saint Louis encephalitis virus, Brazil. Emerg Infect Dis. 2007 Jan; 13(1):176-8.

14 Pinheiro FP, LeDuc JW, Travassos da Rosa AP, Leite OF. Isolation of St. Louis encephalitis virus from a patient in Belém, Brazil. Am J Trop Med Hyg. 1981 Jan;30(1): 145-8.

15 Pugachev KV, Guirakhoo F, Mitchell F, Ocran SW, Parsons M, Johnson BW, et al. Construction of yellow fever/St. Louis encephalitis chimeric virus and the use of chimeras as a diagnostic tool. Am J Trop Med Hyg. 2004 Nov;71(5):639-45.

16 Reisen WK. Epidemiology of St. Louis encephalitis virus. In: Maramorosch K, Murphy FA, Shatkin AJ, editors. Advances in virus research. San Diego: Academic Press; 2003. Vol. 61, p. 139-83.

17 Rocco IM, Santos CL, Bisordi I, Petrella SM, Pereira LE, Souza RP, et al. St. Louis encephalitis virus: first virus isolation from a human in São Paulo State, Brazil. Rev Inst Med Trop Sao Paulo. 2005 Sep-Oct;47(5):281 -5.
18 Roehrig JT, Hombach J, Barrett AD. Guidelines for plaque-reduction neutralization testing of human antibodies to dengue viruses. Viral Immunol. 2008 Jun;21 (2): 123-32.

19 Shope RE. The use of a microhemagglutinationinhibition test to follow antibody response after arthropod-borne virus infection in a community of forest animals. An Microbiol. 1963;1 1:167-71.

20 Stefano I, Sato HK, Pannuti CS, Omoto TM, Mann G, Freire MS, et al. Recent immunization against measles does not interfere with the efficacy of yellow fever vaccination. Vaccine. 1999 Mar;17(9-10): 1042-6.

21 Travassos da Rosa APA, Travassos da Rosa JFS, Pinheiro FP, Vasconcelos PFC. Arboviroses. In: Leão $R N Q$, coordenador. Doenças infecciosas e parasitárias: enfoque amazônico. Belém: CEJUP; 1997. p. 208-225.

22 Tsai TF, Mitchell CJ. St. Louis encephalitis. In: Monath TP, editor. The arboviruses: epidemiology and ecology. Boca Raton: Academic Press; 1989. p. 431 58.

23 Vasconcelos PFC, Travassos da Rosa JFS, Travassos da Rosa APA, Dégallier N, Pinheiro FP, Sá Filho GC. Epidemiologia das encefalites por arbovírus na Amazônia brasileira. Rev Inst Med Trop São Paulo. 1991 nov-dec;33(6):465-76.

24 Vasconcelos PFC, Travassos da Rosa APA, Pinheiro FP, Shope RE, Travassos da Rosa JFS, Rodrigues SG, et al. Arboviruses pathogenic for man in Brazil. In: Travassos da Rosa APA, Vasconcelos PFC, Travassos da Rosa JFS, editors. An overview of arbovirology in Brazil and neighbouring countries. Belém: CEJUP; 1998. p. 72-99.

25 Vasconcelos PFC, Travassos da Rosa APA, Pinheiro FP, Travassos da Rosa JFS. Arboviroses. In: Focaccia R, Veronesi R, editores. Tratado de infectologia. São Paulo: Atheneu; 2005. Vol. 1, p. 289-302. 